KA N D A I

\begin{tabular}{|l|l|l|}
\hline Volume 16 & No. 1, Mei 2020 & Halaman 96-110 \\
\hline
\end{tabular}

\title{
MEMORIZING PROPAGANDA OF EQUALITY IN NGULANDARA AND KIRTI NDJOENJOENG DRADJAT, NOVELS OF BALAI POESTAKA (Mengingat Kembali Propaganda Kesetaraan dalam Novel-Novel Balai Poestaka, Ngulandara dan Kirti Ndjoenjoeng Dradjat)
}

\author{
Yohanes Adhi Satiyoko \\ Balai Bahasa Daerah Istimewa Yogyakarta \\ Jalan I Dewa Nyoman Oka 34, Yogyakarta, Indonesia \\ Pos-el: dhimassetiyoko@gmail.com
}

(Diterima: 7 Mei 2019; Direvisi: 10 Maret 2020; Disetujui: 10 Mei 2020)

\begin{abstract}
Abstrak
Kesetaraan manusia merupakan isu besar yang harus selalu dijaga di setiap negara. Indonesia adalah salah satu negara yang harus tetap berjuang menjaga isu tersebut. Karya fiksi berfungsi sebagai salah satu peranti estetis untuk mendukung isu tersebut. Cara memperjuangkan isu tersebut ialah dengan mengingat kembali masa kemerdekaan melalui penerbit Balai Poestaka. Novel-novel berbahasa Jawa, Ngulandara dan Kirti Ndjoendjoeng Dradjat ialah dua karya sastra yang diterbitkan oleh Balai Poestaka yang ditulis pada waktu dominasi Balai Poestaka sebagai komisi bacaan rakyat di era kolonial Belanda di Indonesia (Hindia Belanda). Kepriyayian merupakan tema novel Ngulandara (1936) dan Kirti Njoendjoeng Dradjat (1924). Dilihat dari sudut pandang propaganda, penggambaran priyayi merupakan analogi simbol pemerintah kolonial Belanda yang berkuasa mengatur sistem sosial kemasyarakatan. Ngulandara dan Kirti Ndjoendjoeng Dradjat menunjukkan sebuah "perjuangan" melalui karya sastra seperti digambarkan melalui wong cilik yang berjuang melawan kemapanan penguasa. Perjuangan tersebut muncul dengan cara wong cilik tersebut bertindak secara intelektual, bermoral, bahkan bersikap lebih terhormat daripada para priyayi. Penelitian ini menggunakan teori sastra dan propaganda dengan pendekatan sosiologi. Relasi oposisional antara dekonstruksi priyayi dan bangkitnya wong cilik dalam ranah intelektual, moral, dan sikap menunjukkan propaganda kesetaraan manusia melalui suara Jasawidagdo dan Margana Djajaatmadja.
\end{abstract}

Kata-kata kunci: kesetaraan, propaganda, priyayi-wong cilik, Balai Poestaka, novel-novel Jawa

\begin{abstract}
Equality of men is a great issue to maintain every country all the time. Indonesia is one of them which should struggle to maintain it so far. Fictional work is one of the aesthetical means to support it. The way of struggle can be memorized through the time of independence era in fictional works of Balai Poestaka publisher. Javanese language novels, Ngulandara and Kirti NdjoendjoengDradjat are two literary works published by BalaiPoestaka that were written in the dominance times of Balai Poestaka activities as commission for people's reading in Dutch colonial era in Indonesia (Dutch Indies). Kepriyayian (nobility) was the theme of Ngulandara (1936) and Kirti NdjoendjoengDradjat(1924) novels. As seen from propaganda point of view, ideologically the portrayal of priyayi (nobleman) was analogy symbol of Dutch colonial government that ruled social system. Ngulandara and Kirti Njunjung Drajat showed a "struggle" through literary works as portrayed in wong cilik (Javanese: lower class people) who struggled against the existence of the authorities. The struggle emerged in the way of wong cilik behaved intellectually, morally, even mannerly better than the nobles (priyayi). This research used the theory of literature and propaganda using a sociological approach. Those oppositional relationships between deconstruction nobles and the raise of wong cilik in the
\end{abstract}


field of intellectual, moral, and manner show the propaganda of equality of men through the voice of Jasawidagdo and Margana Djajaatmadja.

Keywords: equality, propaganda, priyayi-wong cilik, Balai Poestaka, Javanese novels.

DOI: $10.26499 / j k . v 16 i 1.1410$

How to cite: Satiyoko, Y.A. (2020). Memorizing propaganda of equality in Ngulandara and Kirti Ndjoenjoeng Dradjat, novels of Balai Poestaka. Kandai, 16(1), 96-110 (DOI: 10.26499/jk.v16i1.1410)

\section{INTRODUCTION}

\author{
If we refer to the nineteenth century \\ as the Age of Ideology, then it seems \\ even more appropriate to regard the \\ present century as the Age of \\ Propaganda \\ A.P. Foulkes 1983 -
}

Literary work is a mirror of society. Men could see civilization from literary works from time to time. Therefore, literary work documentation through publication has a significant role in providing readings for people to view a journey of civilization. Indonesia with its Bhineka Tunggal Ika (unity in diversity) motto has shown the model of unity in diversity, but nowadays it seems like turn down by particular movement to break the brotherhood of the nation. Living with diversity means living with any great animate differences. There is teasing of popularity and the sense of self introverting (Simarmata, 2017, p.118). Nowadays, in Indonesia through media and physical movement appears a sense of hate, intolerance, and egoistic of groups uncontrolled. Some "vehicles" are taken to show off power to decrease others. Some people feel to have higher privilege, level, title, and truth over others. This chaos of unity has to be immediately recovered. Although the symptoms of intolerance are found worldwide, specifically in Indonesia, it must be recovered with proper strategy. Any elements of the nation must be responsible for it, and literature is as well. Literature presents as a mirror of society at the time and it educates people aesthetically. Sounds of tolerance and equality need to set up.

Two memorable novels from the colonial era, Kirti Njoenjoeg Dradjat (first published in 1924) and Ngulandara (first published in 1936) published by Balai Poestaka are examples literary works to portray the behaviour of men in different cultural background demonstrated in the main characters. They talked about difference, equality, and tolerance of men. The background of the war in Dutch colonial in Indonesia has shown social rule in the interaction between local people and Dutch people. The presentation of the characters explicitly show moral and rule teaching human interaction, as most books published by Balai Poestaka. Publication in the Dutch colonial era in Indonesia had a significant role among any efforts to gain independence releasing from the colonial system by the Dutch Government. Novels published by Balai Poestaka (between 1917-1942) mostly expressed didactic themes due to moral teachings. The moral themes were dominant for the Indonesia condition before the independence under "supervision" from the Dutch colonial government. Some didactic themes were "passed" by government publisher, Balai Poestaka including Panji Poestaka and Kejawen newspapers. Nevertheless, the private publisher also appeared, such as Tan Swie, Pancasaudara, and Boekh Astra (including magazines and newspapers, Darma Kandha, Jawi Hiswara, etc) (Widati, 2001, p. 69).

Balai Poestaka or Volkslectuur was found by Dutch Indies Governor in 
Jakarta in 1908. The goal was to make Indonesian people to be good at reading, particularly for young people after school to read preferred readings provided by the colonizing government. It was prohibited for the youth to read reading materials published by private publishers at that time, like books containing political discussion against the goal of the Dutch colonial etc. (Iskandar, in Kratz, 2000, p. 7). It means that Balai Poestaka, as considered as official and government publisher had shown its existence as "proper" reading providers for graduated and students of state schools. (Pamoentjak, 1948, p. 1517; in Widati, 2001, p. 72). Therefore, any writers and agents due to writing and publishing books were recommended by the Dutch government.

Javanese writers were those who were educated proposed by the Dutch government for they were considered as good writers, experienced in having a relationship with Dutch people. They were mostly the elite priyayi (noble rank in Javanese kingdom or feudalism society). Therefore, during their study in Dutch, they understood the western way of thinking. In the effort to colonize the indigene, the Dutch government made relation to elite priyayi as a political partner (Widati, Sri., 2001, p. 72). On the other hand, the policy to educate the indigene (the pariyayi) was actually ethical politic of the Dutch to camouflage their goal in holding the colony any longer. On the other hand, the privilege of the priyayi appeared mutualism symbioses between the Dutch colonial and the elite priyayi as political partner. Actually, it benefited some elite priyayi.

Most elite priyayi wrote literary works published by Balai Poestaka. Most of them portrayed the social life at that time, particularly the life of the priyayi, common people, and Dutch people in Java Island. In the eye of the Dutch government, Balai Poestaka was the guarantee agent to maintain the untouchable authority in Dutch Indie (Indonesia), but it was different in the eye of priyayi authors who were ever educated in Dutch. Two prominent novels, Kirti Ndjoendjoeng Dradjat by Jasawidagdo published by Balai Poestaka in 1924, and Ngulandara by Margana Jayaatmaja firstly published by Balai Poestaka in 1936 illustrate the world of priyayi. Backgrounded by the era of Dutch colonialism, those two novels portrayed interaction between priyayi and common people in the light of western advanced technology adopted by the indigene. Nevertheless, there some conflic of characters appeared between common people, even lowerclass people, and priyayi in their daily life in searching of the existence and admittance of the status of priyayi. The question of priyayi status was the prominent problem to discuss in searching of the ideology of those literary works, Kirti Ndjoendjoeng Dradjat and Ngulandara.

\section{THEORETICAL FRAMEWORK}

Kirti Ndjoendjoeng Dradjat (KND) and Ngulandara (NG) are mostly talked in any academic and popular books. Ikhtisar Perkembangan Sastra Jawa Modern Periode Prakemerdekaan, a summary of Javanese literary development book published by Balai Bahasa Yogyakarta in 2010, stated that those two literary works were considered as important novels in modern Javanese literary development. Kirti Ndjoendjoeng Dradjat was recorded as a Javanese language novel which has significant role in showing the advanced of indigene way of thinking. Besides that, Ngulandara was also stated as important novel for its voice to tell a 
travel writing in Javanese literature as literary works in Javanese model. The discussion of the travel writing was also discussed in the research entitled Kisah Perjalanan Dalam Sastra Jawa, (Prabowo, 1995) published by Departemen Pendidikan dan Kebudayaan, Jakarta.

Moral theme and issue of equality of men are also stated in some academic writings of undergraduate and postgraduate degrees, such as in "Analisis Sosial Budaya dalam Novel Kirti Njunjung Dratar karya R.Tg. Jasawidagda dan relevansinya sebagai bahan ajar berbasis pendidikan karakter di SMA" written by Sofyan Arif Candra Sakti (undergraduate thesis, 2016). Discussion of hybridity was also written in "Hibriditas Manusia Jawa: Kajian Poskolonial Atas Tokoh Utama Noven Kirti Njunjung Drahat Karya R. TG. Jasawidagda" by Brenkhi Yuhana Purwa (2015, thesis of postgraduate degree, Faculty of Cultural Science, Diponegoro University). Sociological approach was also used to portray Ngulandara novel such as in "Analisis Sosiologi Sastra Novel Ngulandara dalam Kumpulan Novel Emas Sumawuring Baluwarti Karya Partini B dan Pembelajarannya di SMA" by Adi Prasetyo (2015). The literary review shows how those two Javanese novels are relevant to the discussion of human interaction issues.

In the tight screening of Balai Poestaka's editors to the published books of Balai Poestaka, the priyayi life as the most dominant theme of literary books such as Ngulandara and Kirti Njoenjoeng Dradjat, and the question of the existence of priyayi among society have been the problems to discuss. Specifically, the problem to the discussion will be formulated as the questions as follow. (1) How was the portrayal of Balai Poestaka in publishing Javanese literary works during the Dutch colonial era in Java island? (2) What is the ideology of those two novels, Ngulandara and Kirti Njoenjoeng Dradjat in presenting the ideal life and opposition between priyayi and wong cilik?

The goals of the research are to portray the activities and policy of Balai Poestaka in publishing literary works during the Dutch colonial era and to find the ideology of those two novels, Kirti Ndjoendjoeng Dradjat and Ngulandara by presenting the life of priyayi, wong cilik, and the conflict among them.

\section{RESEARCH METHOD}

The discussion is conducted in a literary and propaganda theoretical framework. Propaganda, according to Kamus Besar Bahasa Indonesia is devoted to the spreading of a particular idea or belief. One of the ways is through journalism (Birchwood et.al., 2013 , p. 564). It implicitly means to enlighten (understanding, opinion) that is right or wrong as developed in order to convince people to follow a particular way, attitude, or action. Propaganda can berun openly or in silent. The terminology of propaganda becomes the operational foundation in this research due to Foulkes opinion in Literature and Propaganda (1983).

Aspects that need to be understood in discussing literary and propaganda was social condition and history as the place of the propaganda was made, when, and why the propaganda appeared, to whom propaganda was served, how the propaganda was 'used' and by who. Foulkes (1983:8) in Literature and Propaganda stated that propaganda functions as a system or a series system and tries to differentiate from any other communication forms. Furthermore, the discussion about propaganda would be clearer if the time 
background was set or focused on particular historical background, such as wartime where it was easy to compare and to identify communication as expected to demoralize enemy (Foulkes, 1983 , p. 8). In cultural context, dealing with the literary works analyzed (in the age of colonial-era of Dutch in Dutch Indies), literature can be explicated only by investigating the discourse within which a particular text that was historically produced and received, it does imply a rejection of the notion that the essence of literature should be seen as a sort of aesthetic timelessness which has the power to speak to us across the ages (Foulkes, 1983, p. 105). The idea of Foulkes bases the methodology of investigation through Kirti Ndjoendjoeng Dradjat and Ngulandara novels as published in the era of Dutch colonial in Dutch Indies (Java Island, Indonesia).

Furthermore, operationally propaganda could be operated through activating propaganda potential (Taylor, in Foulkes, 1983, p. 9). Propaganda was categorized into four forms. Ellul (in Foulkes, 1983, p. 10) stated propaganda into 1) Political and sociological propaganda; 2) Agitation and integration propaganda; 3) Vertical and horizontal propaganda; and 4) Rational and irrational propaganda. The political and sociological propaganda is an activity of 'inner persuasion' (Ellul, in Foulkes, 1983 , p. 11) conducted when an individual accepted and assimilated with economic and political ideology from society and use them as the basis to make anything as considered a spontaneous choice and judgment to values. The discussion with this method will be completed by some statements about sociology by Peter Berger in Social Interpretation of Reality that shows the reality among society has the knowledge to understand.
According to the understanding of activities of the propaganda, then the research method is conducted in two steps, gathering written data from the main source in the material books, Nglandara and Kirti Ndjoendjoeng Dradjat, then analyzing those data by using the theory of propaganda and variable supporting written information data to explain and discussing the problem formulation.

The discussion is presented by, the first is explaining the social, political, and cultural circumstance behind Balai Poestaka activities, particularly in the way of publishing the reading books and the Dutch colonial government policy behind the publishing. The second discussion is about to reveal the ideology of those two novels, Ngulandara by Jasawidagdo and Kirti Njoendjoeng Dradjat by Margana Jayaatmaja. The discussion reveals the writers of those two Javanese novels, the voice of the novels, and the addressed goal of the ideology in the background of Second World War, particularly the Dutch colony in Dutch Indie (Java, Indonesia). The discussion uses political and sociological propaganda.

\section{DISCUSSION}

\section{Balai Poestaka and Priyayi-Centric Novels}

The discussion focused on time background in the Dutch colonial era, around $1917 \mathrm{~s}$ to 1945 . At that time, the independence movement of Indonesia faced many problems. The Dutch government in Dutch and in Indonesia tried hard to force any nationalism rising in many ways. One of them was publishing folk books. Therefore, it was built a "barrier" to control understanding about folk's knowledge by building a folk reading library (taman bacaan 
rakyat) that then became Balai Poestaka. Balai Poestaka was existed to provide any readings, such as readings in Malay, Sundanese, and Javanese language.

Development of Javanese language novels in Balai Poestaka era was in line with the issue of Nota Rinkes or D.A. Rinkes thought that initiated etische politiek for Indonesia, after the cultuur stelsel era, a suffered Indonesian political era. It was then built Comissievoor de Inlandsheen Volklectuur in 1908 that became Balai Poestaka. The etische politiek was actually an effort of the Dutch government to make Indonesian people feel close to Dutch (Rosidi, 1986:3). Although Balai Poestaka was set to provide reading for people, it cannot be denied that it was the way of the Dutch government to stay longer with its authority in Dutch Indie. Hence, there was appear twofold 'thought' that was opposite with Rinkes. Balai Poestaka chose Javanese writers who had a similar thought to the Dutch government. Most of those writers were the priyayi (noblemen) who worked in the governmental institutions or teachers of state schools.

During the process of publication, the investigation on the works was very tight. It was performed to avoid national ideology appearance caused by readings published from private publishers. Balai Poestaka aimed to provide readings that guided people to avoid understanding on socialism or nationalism which could stimulate them to fight against Dutch (Alisjahbana, 1992, p. 20).

In 1848 the Dutch in Indonesia received authority from the Queen in Netherland to spend $f 25.000$,- every year for school studying activities. The school was built for indigene children, particularly the priyayi ones who would be local workers. The local workers were needed by the Dutch government for exploitation benefit, for the cheaper cost to pay local officials compared with officials from Netherland (Rosidi, 1986, p. 14). On the other side, as the impact of opportunity to attend school, there appeared awareness from students to like any readings from local and abroad, particularly in the Dutch language. This awareness stimulated patriotic spirit and nationalism to understand and realize their existence as people who were colonized.

Moreover, the people who had finished western education became aware of nationalism struggle. Using their ways, they expressed ideas and opinion through writings, particularly literary works. Those writers group had writing talents for their western educational and cultural background. Some of them were R.Ng. Jasawidagdo, R.B. Soelardi, R. Sastraatmadja, R. Sri Koentjara, R. Ng. Wirawangsa, and Margana Djajaatmadja. While some literary works with the priyayi-centric theme were Kirti Ndjoendjoeng Dradjat (1924), Negara Mirasa (1930), Kepaten Obor (1931), Pati Winadi (1932), Dendhaning Angkara (1932), and Ngulandara (1936).

Balai Poestaka publisher at that time was identical with Dutch colonial in Dutch Indie (Indonesia). Balai Poestaka writers were those who were educated in Western. The priyayi theme at that time was prominent as the colonial government always tried to hold political friendship. Therefore, most of the literary works written and published by Balai Poestaka revealed soft idioms and presented ethic, aesthetic, moral norms, and priyayi life illustration (Quinn, 1992, p. 24). Therefore, in Balai Poestaka era occurred tight interrelated system among writer, publisher, and reader. Balai Poestaka published books written by indigene writers with tight legitimation and permission from people's reading 
commission of Balai Poestaka. This situation set readers to obtain 'prepared' readings so that they received entertainment and knowledge readings which were far from nationalism thought that potentially disturbed Dutch stability in Dutch Indie. The applied system by Balai Poestaka became a logic system because Balai Poestaka was a publisher in Indonesia owned by Dutch in the preindependence era.

\section{Awareness of Balai Poestaka writers for Propaganda}

Operating system in Balai Poestaka publisher was managed by two 'big parties', the Dutch government and distinguished officials of Dutch Indies. Operationally, Balai Poestaka accommodated Javanese literary works to produce, but on the other side, the literary works received tight supervision from commission for people's reading of Balai Poestaka. If the literary works were appropriate to the rules from folks reading commission, they would be published.

Javanese writers of Balai Poestaka were they who received higher education and wide knowledge, including knowledge about western thought. Their knowledge was supported by their ability to master the Dutch language. Their developing knowledge finally gave awareness to keep struggle in educating Indonesia people thought through readings. Those writers had been a system of Balai Poestaka, as writers. Writer was a potency to be activated as a propaganda agent through writings, that was giving education and enlightened who read literary works to comprehend the content of knowledge about nationalism.

\section{Priyayi centric as Propaganda Theme}

Propaganda potency activation of the writer of BalaiPoestaka was performed by Margana Djajaatmadja and R.Ng. Jasawidagdo through their Javanese language novels entitled Ngulandara and Kirti Ndjoendjoeng Dradjat. Priyayi centric theme in colonial times had established Javanese idioms and priyayi life. Kirti Ndjoendjoengdradjat and Ngulandara had realistic story background, about society in the Dutch colonial era which still adored kepriyayian (nobility). The realistic background could be meant that place, time, and situation background were very close to the writer life of Kirti Ndjoendjoeng Dradjat, $\quad \mathrm{R} . \quad \mathrm{Ng}$. Jasawidagdo and Ngulandara, Margana Djajaatmadja. The fact in daily life was a realistic experience. The experience was undergone by the writers in a particular place and time. The realistic and subjective experiences were unique. Therefore the uniqueness was linguistically typified into a sentence category or utterance that show theme from meaning that was revealed from typification or language symbolization (Light et al., 1967, p. 55). This way made the real biographical experience that was categorized to common meaning groups objectively or subjectively (Light et al., 1967, p. 55). Moreover, (Light et al., 1967, p. 6) stated that the way language worked was by saying that language was able to transcendent whole real daily life. The language could refer to experience that cover tangible meaning and it could reach real different areas.

Typification in Kirti Ndjoendjoeng Dradjat and Ngulandara was obtained from the interaction of priyayi characters, "wong cilik", and people around them. Priyayi or noblemen were the society one right under the king. 
They were family and relatives of the king who obtained ascribed noble status (Soeratman, 1989, p. 318). Moreover, according to Magnis-Suseno (1988), noblemen's way of life was almost similar to the king's. Some of the ways were the orderliness of rule in daily activities more than common's people did. The materialistic-economic became strict differentiator between the life of priyayi and "wong cilik".

Moreover, (Geertz, 1983, p. 6) portrayed "wong cilik" as a group of people who were unable to release themselves from physical and materialistic world, for they were a group of farmer in villages. Then, (Geertz, 1983, p. 317) stated that wong cilik also owned unrespectfulness and disorderliness in caring children. It means that, functionally, the existence of priyayi and "wong cilik" had symbiosis in their social life intention to fulfill daily needs. In Kirti Ndjoendjoeng Dradjat and Ngulandara the presentation of wongcilik character as represented by Darbaanda Rapingun had built uncommon relation in authority system in colonial era. The relation between priyayi-"wong cilik" stimulated conflict that functioned to show particular signs to be a writer ideology. The conflict was divided into four that showed "opposition" to nobility social system domination.

\section{Kepriyayian and Its Achievement}

Achievement of priyayi status for indigene people or "wong cilik" was not a certainty. Working in government offices to obtain priyayi status needed apprenticeship for eight years at least.

\footnotetext{
"Wis pirang taoen, le, oleh moe magang?"

"Kalih taoen."

"Wah isih tangeh."
}

\section{Temboengipoen mas bei Mangoenripto poenika tegesipoen: taksih tangeh sagedipun dados prijantoen amargi adatka limrahipoen, magang punika pantjen pitoe woloeng taoenan. (KND, 1924, p. 5).}
"How long, Boy, are you working in an apprentice?"
"Two years."
"Huh, still impossible."
Mas Bei Mangoenripto words mean: it is impossible to be a noble in natural way of apprenticeship at the office for it really needs seven to eight years. (KND, 1924, p. 5).

The conversation between Darba and Mas Bei Mangoenripta illustrated a long time to obtain noble status. Nevertheless, during the apprentice, someone was not guaranteed to obtain it successfully. The noble status was identical to honour and welfare. It means, every citizen who still lived under the welfare limit at that time tried to obtain the noble rank with the guarantee of welfare and honour. That way became idol ways for everybody with an idealism to achieve priyayi status, with having a status names before their real names. Priyayi means to obtain a good job and honourable, living wealthy, having a relationship with highrank people in society, like the priyayi, Dutch people, Chinese, and any other higher social rank people.

\section{Leaving Nobility (Kepriyayian)}

Nobility means nothing. At least it was expressed by Darba's attitude in gaining honourable by leaving nobility. In fact, apprenticeship to obtain noble rank in the normal way needs patience. This patient did not guarantee success, because it was all depended on the 
officials. This way to reach the nobility was opposed by Darba by working hard through the way he trusted, by working in Steel Factory, Linda-Teves Stokvis in Semarang. The obtaining esteemed status in Javanese society, which was presented with noble (priyayi) status and the rank was opposed by working hard and became famous for his skill as bicycle labour.

Tetela Darba toekang pit poenika inggih Darba ingkang nilar kaprijantoenan kala sangang taoen kepengker. Wontenipuning Semarang saestoen jamboet damel wonten ing pabrik barang tosan Linda TevesStokvis. Ingkang dipoen parsoedi Darba, prakawis nggarap tosan, kedjawi poenik amanawi daloe njambi sinaoe tjaraWalandi, sarenganipoen kathah, djoeroe serat sasaminipoen, ngantos sasampoenipoen kawan taoen Darba angsal diploma klein-ambtenaar (KND, 1924, p. 49).

Indeed, Darba the bicycle technician is Darba who left his nobility behind nine years ago. His existence in Semarang really works in a steel factory, Linda Teves-Stockis. He expects and works of making steel, but at night Darba also study about the Dutch language, with many students, his clerk friend, until mister Darba obtained diploma kleinambtenaar(KND, 1924, p. 49).

Esteemed achievement status had been reached by Darba without passing the conventional way as common people did. The attitude of Darba shows that nobility is nothing compared with knowledge. The profession of Darba also satirically addresses to the noble (priyayi and Dutchmen) that any job either it is highly esteemed or low esteemed among society is the same. The equality of the status lies on the seriousness, skill, fair, and sincerity. This voice of equality is shown in the profession of Darba as a bicycle technician with high esteemed from society. The social status of Darba is shown in the quotation that says the Dutch, Chinese, Java costumers are completely satisfied with the work of Darba.

Tamoenipoen pating sliri: Walandi, Tjina, Djawi, sedaja katingal marem ing manah, amargi dhatengipoen dipoentampeni sae, wragad andandosi: oeroep, malah ketang mirah katandhing kalijan saening garapan (KND, 1924, p. 48).

The customers are many: Dutch, Chinese, Java, all of them look like satisfied, for their visiting is well welcomed, cheap price with good quality service. (KND, 1924, p. 48).

The well-known, Darba received honourable status from society because of his low profile and knowledge he obtained and applying to his talent.

\section{Kepriyayian, Moraland Manner}

Priyayi is believed as a source of wisdom and guidance of life. The priyayi in Ngulandara and Kirti Ndjoendjoeng Dradjat was portrayed in opposition to their conducts. Some are portrayed as in some depiction, as in Kirti Ndjoenjoeng Drajat. The depiction shows improper attitude and behaviour of a priyayi, Mas Bei Mangoenripta who was angry and mad at village people who wanted to sit beside him in a train.

"Mas Bei Mangoenripta nepsoe, ladjeng ngoengel-oengeli tijang doesoen waoe:....heh, apa ora weroeh jen akoe prijaji." (KND, 1924, p. 6) 
"Mas Bei Mangoenripta was angry, then grumble and scream on the villager: ....heh, don't you know that I am a nobleman." (KND, 1924, p. 6)

The quotation shows an arrogant priyayi who is deadly proud of himself and show off himself as a priyayi. This character is against the nature of priyayi who is afraid to express emotions for it stimulate frustrations. Priyayi always keeps his manner to show his mature emotion. He always tries to keep any problem inner himself, to manage social interactions, and to live friendly to others (Suseno \& Magniz, 1988, pp. 98-99). The statement shows interrelationship that priyayi should own moral attitude as the attached character, not showing degrade moral and manner. Hence, the depiction above emerges the question of the existence of the "mature" priyayi as he should be.

\section{Kepriyayian and Intellectual}

Kepriyayian was identical to ability and power which became a guide to the social class below. Nevertheless, in Kirti Ndjoendjoengdradjat and Ngulandara, the priyayi characters were portrayed as persons who did not have knowledge and skill, particularly in mechanical and engineering. In Kirti Ndjoendjoeng Dradjat it was shown that Rapingun was a private driver who was skillful to repair car engine. Rapingun was very clever in treating machine he faced. His self-confidence was shown in his statement to guarantee that the engine he repaired would be back to normal.

\footnotetext{
Busi ingkang kabikak sampun

kapasang malih, sarta sanesipun sampun kentjeng sadaja, kekeping motor dipuntutupaken malih, sopir ladjeng sandjang:
}

\author{
"Samangke tanggel, gesang \\ motoripun ndara!” (NG, 1957, p. 11)
}

The sparkplug has been set again, and the other ones have been tightened up, the fairing has been set up again, the driver then says:

"I guarantee, your motor will work well” (NG, 1957, p. 11)

In Kirti NdjoendjoengDradjat, the character of Darba was portrayed having ability and skill more than the average to the youth. Darba was able to read Dutch language, good at rhetoric, skilful in mechanical. Ability in reading and writing in the Dutch language, strong intention to face any social-cultural phenomena in front of him, and ability in mechanical as shown in some quotations below.

"Penapa poetrane punika sampoen saged njerat djangkep, Mas?"

"Sawatawis, rekanipun poenika tamat pasinaonipoen saking pamoelangan ing Batangan. Samangke toemoet sinaoe tjara Walandi wontening Abipraja."

"O, pamoelangan Walandi partikelir saben sonten poenika. Ingkang ngadani rak den bei Pradjamartana, ta. heh, ana-ana wae wong-wong toewa padha reka-reka sekolah, koewi gek arep golek dienggo apa." (KND, 1924, p. 5)

"Has your son been capable in writing, Mas?

"Quite good, I expect after finishing his study in Batangan, then he continues to study Dutch manner in Abipraja."

"O, Dutch Private study is in every afternoon held by Den Bei Pradjamartana, heh, wasting for the elderly who search for a school, what are you looking for." (KND, 1924, p. 5) 
In Den Bei Pradjasoesastra's home, Darba received many opportunities to read the newspaper, like DjawiKandha. Therefore, it is not surprising if Darba became knowledgeable. The quotation showed that what Darba did was uncommon at the time, particularly in the eye of Mas Bei Mangoenripta, a priyayi who underestimated people beyond his social group. So, it was not surprising if, with his rhetoric ability, Darba could make friendship and relation with the higher classes' people. Once in a meeting in kraton, he was elected as leader of the group. His ability and skill in mechanical which was initiated with his ability in repairing bicycle became good result when finally Darba could build a bicycle workshop in Semarang.

\section{Self Confidence Spirit of Wong Cilik}

Priyayi, ideally, has model character as low profile, good looking, simple appearance, cautious to any matters, good problem solver. These characters were shown in Ngulandara by the presentation of Rapingun character. Rapingun was a priyayi who "undergoes" as common people to search knowledge of life.

In old Javanese tradition, priyayi sometimes performed incognito. It means the priyayi behave to be common people. This manner is the travel of life of priyayi to find knowledge in any situation and places by meeting anybody. He sometimes did travel to enrich himself with the value of life by doing any benefited job.

The philosophy of travelling to find more knowledge of life is universal conduct. Some ways were undergone by the travellers. One of them can be viewed in Serat Centhini, a book of "Javanese Encyclopedia" compiled by Mangkunegara $\mathrm{V}$ in gathering data from his disciples after travelling around Java. Moreover, it was different from Marcopolo in his travelling by himself to meet Asia continent which then recorded as Livres des Merveilles du Monde. On the other side, Darba in his travelling performed incognito as "wong cilik" or common people. As in Kirti Ndjoendjoeng Dradjat, Darba wanted to enrich himself to be knowledgeable in mechanical by leaving his family in Surakarta and worked at the repair in Semarang.

The statement of Darba shows that welfare depended on our efforts to go ahead. This statement was also stated among indigenes. Spirit of struggle against "destiny" of life had been triggered by Darba to show a rational way of thinking in facing life. Diligent, spirit, and never say die in undergoing any situation was the point of Darba's idealism as stated in the following quotation.

Dene satoenggal-satoenggaling
tijang, poenika soegihipoen
goemantoeng wonten
kasregepanipoen njamboet damel.
Sinten ingkang pethel sarta gemi,
inggih soegih. Sinten ingkang kesed
toer boros, inggih katjingkrangan
(KND, 1924, p. 53)

Every person's welfare depends on his diligent in working. Those who are serious and economical will be rich. Those who are lazy and wasteful will be poor (KND, 1924, p. 53)

Furthermore, self-confident of wong cilik to the authorities was symbolized in the occurrence when Darba refused to be paid by a Dutch machines who was helped by Darba when he and his son were fallen from their bicycle. At the time Darba refused wage as payback for Darba felt that he was not "waged labour" as common 
people at the time, a lower status to the Dutch machines. Darba felt like a sort of person who was equal to the Dutch machines.

\section{Sareng sampoen saged ngadeg} sajektos, ladjeng moeroegi Darba, kanthi ngoeloengi arta saroepijah, sarta badhe mbopong sinjo ingkang taksih kapondhong Darba.

Darba nampik dhateng paweweh poenika witjantenipoen aloes:

"Toewan, sampoen dados panggalih, koela boten ngalap epah, aloewoeng manawi kepareng, sinjo poenika koela gendhongipoen, pandjenengan noentoen pit. (KND, 1924, p. 28).

After he had stood up properly, he came close to Darba to give money one rupiah and would to hold the Dutch boy who was still carried by Darba.

Darba refused the gift of the person tenderly: "Sir, don't be annoyed, I am not asking for paying back, if you don't mind, I will carry this boy, you push a bicycle by hand (KND, 1924, p. 28).

Moreover, Darba also gave a hand to help by carrying the son on his back. This attitude shows the confidant of the indigene when facing the Dutch. The attitude of Darba showed a brave for igniting equality among indigene and foreign people.

\section{Nobility (kepriyayian) and Ideology of Equality}

Social-cultural variety as concluded in fictional work, either in fictional setting or historical (realist) is the combination of reality and fiction. The reality in any forms and setting characters in the literary works with its background shows a sign or broader meaning from the reality itself. In the fictional work, the use of reality in simulation not only address to the willingness to copy familiar reality for us, but its function is to create us to see familiar reality with new vision (Iser, in Satiyoko, 2012, p. 2).

Ideology, in prosaic works, particularly novel according to Quinn, (1992, p. 141), is the body of the interrelation of the idea, certainty, attitude, institution, artefact, and practices which clarify or at least dealing with well-known society group attitudes. Moreover, (Geertz, in Quinn, 1992, pp. 141-142) stated that ideology appears as effort symbolically to vanish conflict and handicaps. "Ideology gives "symbolic explanation" to emotional annoyance as constructed by social imbalance. Kirti Ndjoendjoeng Dradjat and Ngulandara novels as they were published in colonized era have kepriyayian (nobility) ideology. The priyayi novel orients to conservative and ideological. The perspective and discussion about priyayi novel are inseparable from ideology of middle-high class society in Java who occupies high status, 'progressive' officials, rich professionals, entrepreneur, and mother householder, and little nobles (Quinn, 1992, p. 145). Priyayi ideology on Javanese novel appears as Javanese cosmic view during the colonized era, Dutch colonized over Indonesia (Dutch Indies).

Presentation of the characters of Darba and Rapingun functionally roles as wong cilik is opposed with priyayi. Priyayi ideology as portrayed in Kirti Ndjoendjoeng Dradjat and Ngulandara lies on achievement in noble rank for it has an important function for the one in which the tittle names placed before the real name. The pride of a priyayi also comes from the admittance that he obtained the title from ascendance. Besides that, the power of priyayi comes from economic power as they occupied a strategic position of famous states or 
privates offices. Nevertheless, beyond those factors, nobility (kepriyayian) ideology also establish a vision that priyayi power is considered 'natural' and is run without any handicaps, as if it goes to with rules of natural cosmic to gain by priyayi, for the sake of he is priyayi (Quinn, 1992, p. 151).

Besides having the ability and never give up attitude to study, the portrayal of wong cilik also shown in Darba's and Rapingun's attitudes while they faced priyayi and the Dutch in some happenings. The first happening was while Rapingun repaired a priyayi's car in the middle of the forest on a rainy night. It shows the pride of the young man facing upper-class people.

Interaction between wong cilikpriyayi in KND and NG novels show a "question" to the elite existence as viewed from society eyes in the Dutch colonized era. The plot of KND and NG shows modernity and sense of universality in people way of thinking as shown in ability and skill of indigenes, Darba and Rapingun to think, behave, and act as the western did, even more. So, it is no wonder if it can be said that in KND and NG there has been mimicry to modernity system in life. Existence of the past and the now are only determined by a chamber of time so, that the two of them are not oppositional. The problem is that people too believed that modernity is identical to the west and traditionalistic is identical to the east (Suwondo, 2016, p. 172). People in common are asked to comprehend that intelligent, moral, vision, is not only originated merely from the Elite Priyayi. People beyond the group also have those abilities as equal to the Elite Priyayi, even more.

The question to the existence of priyayi could be read and understood in a social interpretation as an analogy of indigene power to the Dutch colonized.
The power was translated in the brave of the indigenes to express theirselves in way of thinking, moral attitude, skill and ability to face any new knowledge came from the west. This social reality also shows that people no need to have astonishment to something new came from abroad culture, particularly in technology, for the indigenes actually have power and ability to master. The most important thing is the indigenes have to have the courage to undergo new habit, by working with new knowledge guidance for the knowledge is universal for people all over the world.

Thus, the presentation of Darba and Rapingun is a voice of struggle against the knowledge under pressured created by the Dutch in Dutch Indies (Indonesia) to be stated and stuck in knowledge dullness. On the other side, there appears a voice of equality and freedom to gain knowledge, as in fact, the freedom of Dutch colonized. The analysis above shows sociological propaganda as an activity of 'inner persuasion', in which the writer of Kirti Ndjoendjoeng Dradjat and Ngulandara struggle with inner persuasion using literary works to sound the voice of "subaltern" in gaining equality admittance in way of thinking, moral, manner, and intellectual to the western.

Equality belongs to any aspect of the life of all human living. Every people has equality to others. It is expressed in any characters of human with their universal reasoning like in happiness, sadness, grief, brotherhood, etc. Therefore, it should not be an underestimation, depressing, colonization, the term of subaltern, marginalized. Colonizing is the kind of self distrusted even, self-esteemed for humanity. Kirti Ndjoendjoeng Dradjat and Ngulandara are two literary works expressing satirical drama to those people who are considered as the ruler, 
the power, the author to others. In particular, those two novels satirically said the struggle of colonized people to the colonizer as propaganda not only for independence but also for human equality.

\section{CONCLUSION}

The critical reading of the novels, Kirti Ndjoendjoeng Dradjat and Ngulandara shows propaganda to reveal, moral, manner, and intellectual attitudes of wong cilik and priyayi in oppositional interactions. The oppositional relationship shows a comparison of attitudes of priyayi and wong cilik where there is imbalance conduct of the priyayi who behave degrade in moral, manner, and intellectual. On the other hand, the presentation of wong cilik characters show the intellectually, morally, and mannerly better that the priyayi's. This oppositional condition is the clue of the authors, R.Tg. Jasawidagdo and Margana Djajaatmaja to set propaganda to remind the indigenes that they have the chance to be free from under pressure of the colonial (priyayi is identical social status to Dutch, at that time). It means the status title of the priyayi is nothing, but personal actualization of people is more important to show in social and cultural interaction. This comparison shows the equality of men not of status.

Jasawidagdo and Margana Djajaatmadja want to say that equality of human races will -(?) the individuals and the world without colonization. The peace really needs awareness and knowledge of human being and this has been set by Margana Djajaatmadja and Jasawidagdo through their works Kirti Ndjoendjoeng Dradjat and Ngulandara. The voice of equality should inspire the peace and equality of men nowadays, particularly in Indonesia, the country with various ethnic groups, cultures, and languages to set diversity to be still in unity everlastingly.

\section{REFERENCES}

Alisjahbana, S. T. (1992). Bunga Rampai Kenangan pada Balai Pustaka (p. 20). Perum Penerbitan dan Percetakan.

Birchwood, M., Velickovic, V., Dines, M., \& Fiske, S. (2013). Literary Terms and Literary Theory. https://doi.org/10.1002/978111832 5988

Foulkes, A. . (1983). Literature and Propaganda.pdf (pp. 8,9,10, 11, 105). Methuen.

Geertz, H. (1983). Keluarga Jawa.pdf (p. 6). Grafiti Pers.

Iser, W. (1980). The Act of Reading (Vol. 18, p. 181). John Hopkins University Press.

Iskandar, N. S. (2000). Sejarah Sastra Indonesia Abad XX (p. 7). Kepustakaan Populer Gramedia.

Light, D. W., Berger, P. L., \& Luckmann, T. (1967). The Social Construction of Reality: A Treatise in the Sociology of Knowledge. In Sociological Analysis (Vol. 28, Issue 1, p. 55). Penguin Books. https://doi.org/10.2307/3710424

Prabowo, D. P. (1995). Kisah Perjalanan dalam Sastra Jawa.pdf. Departemen Pendidikan dan Kebudayaan.

Quinn, G. (1992). Novel Berbahasa Jawa.pdf. IKIP Semarang Press.

Rosidi, A. (1986). Ikhtisar Sejarah Sastra Indonesia.pdf (p. 2,3). Binacipta. 
Satiyoko, Y. A. (2012). Wani Ngalah Luhur Wekasane. Pesan Moral dalam Novel Berbahasa Jawa Candhikala Kapuranta karya Sugiarto Sriwibowo (p. 2). Balai Bahasa Provinsi DIY.

Simarmata, Henry Thomas, .dkk. (2017). Indonesia Zamrud Toleransi.pdf.part (p. 118). PSIKIndonesia.

Soeratman, D. (1989). Kehidupan Dunia Kraton Surakarta, 1830 1939(p.1).

https:/www.goodreads.com/book/ show/2370519.Kehidupan Dunia Kraton_Surakarta_1830_1939
Suseno, F., \& Magniz. (1988). Etika_Jawa.Pdf (pp. 98-99). PT Gramedia.

Suwondo, T. (2016). Pragmatisme Pascakolonial.pdf (pp. 98-90). Poestaka Pelajar.

Widati, Sri., D. (2001). Ikhtisar Perkembangan Sastra Jawa Prakemerdekaan.jpg (pp. 69-70). Gadjah Mada University Press. 